\title{
Penerapan Model Quantum Learning untuk Meningkatkan Hasil Belajar IPA Siswa di Sekolah Dasar
}

\author{
Rasmi Djabba ${ }^{1}$, Abdul Halik ${ }^{2}$ \\ 1,2Prodi PGSD Fakultas Ilmu Pendidikan UNM \\ djabba.rasmi@unm.ac.id \\ abdul.halik@unm.ac.id
}

\begin{abstract}
ABSTRAK
Tujuan dari penelitian ini adalah untuk mengetahui penerapan model pembelajaran quantum learning dan meningkatkan hasil belajar IPA siswa kelas V SD Negeri 140 Kabere. Penelitian ini menggunakan pendekatan kualitatif dengan jenis penelitian tindakan kelas. Hasil penelitian ini menunjukkan adanya peningkatan hasil belajar IPA dengan diterapkannya model pembelajaran quantum learning. Hal tersebut menunjukkan bahwa model pembelajaran quantum learning dapat meningkatkan hasil belajar siswa pada mata pelajaran IPA kelas V SD Negeri 140 Kabere.
\end{abstract}

Kata kunci: hasil belajar, quantum teaching

\section{PENDAHULUAN}

IPA merupakan mata pelajaran wajib di sekolah dasar yang bertujuan tidak hanya mengembangkan kognitif, afektif dan psikomotorik siswa namun juga sebagai bekal siswa dalam mengenal alam di lingkungan sekitarnya dan melatih siswa mengambil keputusan dalam menyelesaikan suatu masalah. Guru memiliki peran yang sangat penting untuk mencapai tujuan tersebut dengan merancang suatu proses pembelajaran yang efektif. Suatu pembelajaran yang efektif tercermin dari hasil belajar yang di dapatkan oleh siswa.

Pada kenyataannya pembelajaran IPA di sekolah dasar masih belum efektif sehingga tujuan pembelajaran IPA tidak tercapai sesuai rencana pembelajaran. Hal tersebut yang juga terjadi di SD Negeri 140 Kabere khususnya pada siswa kelas V. Melalui observasi dan wawancara dengan guru dan siswa ditemukan bahwa hasil belajar pada mata pelajaran IPA masih rendah yakni ketika peneliti memberikan tes awal kepada 15 siswa hanya ada 1 siswa yang memperoleh hasil di atas KKM. Hasil belajar siswa ini rendah disebabkan oleh dua faktor, yaitu faktor guru (a) guru menggunakan lebih banyak metode ceramah, (b) guru tidak mampu menarik perhatian siswa, (c) guru kurang mampu memberikan motivasi, sedangkan faktor siswa (a) siswa cenderung pasif dalam proses pembelajaran, (b) siswa lebih memilih bermain-main dalam kelas dan tidak mendengarkan penjelasan guru, (c) siswa kurang termotivasi.

Mengingat pentingnya pembelajaran IPA di sekolah dasar dan kondisi pembelajaran IPA di SD Negeri 140 Kabere, maka perlu dilakukan pemecahan masalah. Adapun pemecahan masala yang digunakan adalah dengan penggunaan model pembelajaran yang tepat sehingga lebih mengaktifkan siswa dalam proses pembelajaran. Oleh karena itu, dilakukan penelian dengan judul "Penerapan Mdel Quantum Learning untuk Meningkatkan Hasil Belajar Siswa pada Mata Pelajaran IPA Kelas V SD Negeri 140 Kabere".

Model pembelajaran Quantum Learning dikembangkan pada sebuah program remaja bernama Super Camp pada tahun 1982 oleh Bobbi DePorter dan kawan-kawan. Istilah quantum memiliki arti interaksi yang mengubah energi menjadi cahaya. DePorter (Nandang Kosasi, 2013:75) mengungkapkan bahwa quantum teaching adalah penggubahan belajar yang meriah dengan segala nuansanya, dan quantum teaching juga menyertakan segala kaitan, interaksi dan perbedaan yang memaksimalkan momen belajar. Adapun prinsip-prinsip model pembelajaran quantum learning yaitu: (a) segalanya berbicara, yakni segala dari lingkungan kelas hingga bahasa tubuh guru, kertas yang dibagikan hingga rancangan pembelajaran semuanya mengirimkan pesan tentang pembelajaran, (b) segalanya bertujuan, yakni semua yang terjadi dalam proses belajar mengajar memiliki tujuan, (c) pengalaman sebelum pemberian nama, 
yakni proses belajar paling baik terjadi ketika siswa telah mengalami informasi sebelum memperoleh nama untuk apa yang mereka pelajari, (d) akui, yakni siswa patut mendapat pengakuan atas prestasi dan kepercayaan dirinya, (e) rayakan, yakni sebagai bentuk umpan balik maka perlu ada perayaan mengenai kemajuan dan meningkatnya asosiaisi emosi positif dengan belajar (DePorter, 2014).

Pembelajaran quantum seperti diungkapkan Bobbi DePorter (2014) memiliki konsep yaitu TANDUR yang merupakan singkatan Tumbuhkan, Alami, Namai, Demonstrasikan, Ulangi dan Rayakan. (1) konsep tumbuhkan, yakni guru harus menumbuhkan motivasi dan semangat belajar siswa serta memberi pengalaman informasi yang terkait dengan upaya pemberian nama, (2) konsep alami, yakni memberikan pengalaman nyata bagi siswa untuk mencoba sehingga siswa aktif dalam pembelajaran, (3) konsep namai, yakni memperkenalkan konsep pokok dari materi pelajaran saat minat siswa memuncak yang disertai dengan data yang ditemukan siswa, (4) konsep demonstrasi, yakni pemberian kesempatan kepada siswa untuk menyampaikan pengalaman yang dikaitkan dengan data baru, (5) konsep ulangi, yakni menunjukkan suatu pengalaman dari materi yang telah diajarkan yang bertujuan memperkuat koneksi saraf, (6) konsep rayakan, yakni memberi perayaan sebagai rasa hormat atas usaha, ketekunan dan kesuksesan serta pada akhirnya memberikan kepuasan dan kegembiraan.

Penggunaan model pembelajaran quantum teaching dengan pengalaman secara langsung maka dapat meningkatkan hasrat alami otak untuk menjelejahi sehingga konsep yang diajarkan siswa berupa informasi yang abstrak dapat dikonkritkan (Sugiyanto, 2010). Seperti diketahui bahwa mata pelajaran IPA merupakan ilmu yang bersifat empirik dan membahas tentang fakta dan gejala alam yang bertujuan untuk melatih dan mengembangkan keterampilan proses untuk bertindak secara rasional dan kritis terhadap persoalan yang bersifat ilmiah yang ada di lingkungannya sehingga dapat diterapkan dalam kehidupan sehari-hari siswa.

Peningkatan hasrat alami otak dengan pengalaman langsung dalam proses pembelajaran dapat berdampak positif terhadap hasil belajar siswa. Hasil belajar adalah merupakan hasil dari suatu interaksi tindak belajar dan tindak mengajar (Dimiyanti dan Mujiono, 2006).

\section{METODE PENELITIAN}

Penelitian ini menggunakan pendekatan kualitatif dengan jenis penelitian penelitian tindakan kelas (PTK). Penelitian ini adalah penelitian praktis yang dimaksudkan untuk memperbaiki pembelajaran di kelas.

Fokus penelitian ini adalah proses belajar mengajar dengan model pembelajaran quantum teaching dan hasil belajar siswa. Penelitian ini dilaksanakan di kelas V SD Negeri 140 Kabere dengan jumlah siswa siswa sebanyak 15 orang yang terdiri dari 7 orang laki-laki dan 8 orang perempuan.

Penelitian ini dilaksanakan dalam 2 siklus tindakan yang masing-masing siklusnya dilaksanakan dua kali pertemuan yang terdiri dari tahap perencanaan, pelaksanaan tindakan, observasi dan refleksi. Teknik pengumpulan data yang digunakan dalam penelitian ini adalah observasi, tes dan dokumentasi. Data kualitatif yang dikumpulkan akan dianalisis dengan tiga tahap kegiatan yaitu:

reduksi data, (2) menyajikan data, dan (3) menarik kesimpulan dan verifikasi data.

Indikator keberhasilan proses pada penelitian ini adalah semua indikator aktivitas belajar siswa dalam proses pembelajaran yang dikatakan berhasil apabila minimal $76 \%$ dengan kualifikasi baik berdasarkan pedoman observasi guru. Adapun indikator keberhasilannya berupa hasil belajar siswa yang jika $76 \%$ atau lebih dari jumlah siswa yang mengikuti proses pembelajaran berhasil mendapat nilai $\geq 75$.

\section{HASIL \& PEMBAHASAN}

Pada siklus I pertemuan 1 menunjukkan bahwa dari 15 siswa hanya $40 \%$ siswa yang mendapat nilai $\geq 75$ dengan hasil nilai rata-rata siswa yaitu 74. Presentasi ketercapaian pelaksanaan pembelajaran pada aspek guru sebesar $70,83 \%$ dan pada aspek siswa juga sebesar $70,83 \%$. Selanjutnya pada siklus I pertemuan 2 menunjukkan bahwa dari 15 siswa hanya $60 \%$ siswa yang mendapat nilai $\geq$ 75 dengan nilai rata-rata siswa yaitu 75,53. Pada presentasi ketercapaian pelaksanaan pembelajaran untuk aspek guru sebesar $75 \%$ dan aspek siswa juga sebesar $75 \%$. Berdasarkan hasil tersebut maka dapat disimpulkan bahwa pembelajaran sudah mengalami peningkatan namun belum mencapai indikator keberhasilan yang telah 
ditentapkan yaitu $76 \%$ sehingga harus dilanjutkan ke siklus berikutnya.

Pada siklus II pertemuan 1 menunjukkan bahwa $73 \%$ siswa telah mendapatkan nilai $\geq$ 75 dengan nilai rata-rata siswa yaitu 76 . Adapun ketuntasan untuk indikator proses pada aspek guru dan siswa mencapai $83,33 \%$. Pada siklus II pertemuan 2 siswa yang mendapatkan nilai $\geq 75$ telah mencapai $87 \%$ dengan nilai rata-rata siswa yaitu 83 . Ketuntasan belajar untuk indikator proses pada aspek guru dan siswa telah mencapai $100 \%$.

Berdasarkan hasil yang diperoleh pada siklus II pertemuan 2 ini maka penelitian tidan dilanjutkan ke siklus berikutnya karena indikator keberhasilan telah tercapai baik dilihat dari indikator proses maupun hasil.

\section{Pembahasan}

Pada tindakan di siklus I pembelajaran dengan materi daur air belum mencapai indikator keberhasilan yang direncanakan. Hal tersebut disebabkan masih kurang baiknya pengelolaan kelas oleh guru dan kurang relefannya apersepsi dan materi yang diajarkan. Selain itu guru guru kurang maksimal dalam membimbing dan menanamkan konsep pembelajaran daur air pada siswa sehingga berdampak pada pemahaman siswa yang masih kurang terhadap materi yang diajarkan. Selain itu ada beberapa siswa yang belum dapat menjawab pertanyaan ketika ditunjuk.

Hasil penelitian pada tindakan siklus I menunjukkan bahwa tingkat keberhasilan proses dan hasil belajar belum mencapai indikator keberhasilan yang ditetapkan sehingga perlu dilanjutkan pada siklus II dengan beberapa perbaikan dalam pelaksanaan pembelajaran. Pada tindakan siklus II indikator keberhasilan yang ditetapkan telah tercapai karena siswa lebih memahami materi yang diajarkan, hal tersebut terlihat dengan keberanian siswa menjawab pertanyaan yang diajukan oleh guru dan siswa sudah mampu melaksanakan indikator-indikator pembelajaran dengan menggunakan model pembelajaran quantum learning. Selain itu, guru juga telah menerapkan langkah-langkah model pembelajaran quantum learning dengan sangat baik.

Berdasarkan hasil observasi perencanaan, pelaksanaan, evaluasi dan refleksi pada silklus II maka disimpulkan bahwa penelitian ini telah berhasil dengan tercapainya indikator dengan presentase ketuntasan yang dicapai pada siklus II sebesar $87 \%$ yang melewati target minimal yang telah ditetapkan. Maka dapat disimpulkan bahwa model pembelajaran quantum learning dapat meningkatkan hasil belajar siswa pada mata pelajaran IPA di kelas V SD Negeri140 Kabere dengan materi pokok daur air.

\section{KESIMPULAN \& SARAN}

Berdasarkan pelaksanaan (tindakan), hasil dan pembahasan penelitian maka dapat disimpulkan bahwa model pembelajaran quantum learning dapat meningkatkan hasil belajar siswa pada mata pelajaran IPA di kelas V SD Negeri 140 Kabere dengan materi pokok daur air.

Berdasarkan kesimpulan dari penelitian ini, maka berikut ini diajukan beberapa saran yaitu: Model pembelajaran quantum learning dapat meningkatkan hasil belajar siswa pada mata pelajaran IPA maka disarankan untuk dapat diterapkan pada mata pelajaran lainnya. Bagi calon peneliti yang ingin melakukan peneltian yang sama hendaknya penelitian ini dijadikan acuan untuk meminimalisir kekurangan-kekurangan selama penelitian.

\section{DAFTAR PUSTAKA}

Ahmad, Abdul., 2007. Media Pembelajaran. DePorter, Bobbi dkk. 2014. Quantum Teaching: Mempraktikkan Quantum Learning di Ruang-ruang Kelas: Penerjemah: Ary Nilandari. Cetakan keII. Bandung: Kaifa.

Dimiyati dan Mudjiono. 2006. Belajar dan Pembelajaran. Jakarta: Rineka Cipta.

Nana, Syaodih Sukmadinata. 2007. Metode Penelitian Pendidikan. Bandung: PT Remaja Rosdakarya.

Sugianto. 2010. Model-model Pembelajaran Inovatif. Surakarta: Yuma Pustaka. 